\title{
Theorizing Economic Geographies of Asia
}

\author{
Henry Wai-chung Yeung \\ Department of Geography, National University of Singapore, \\ 1 Arts Link, Singapore 117570 \\ geoywc@nus.edu.sg \\ George C. S. Lin \\ Department of Geography, University of Hong Kong, \\ Pokfulam Road, Hong Kong SAR \\ GCSLIN@hkucc.hku.hk
}

\begin{abstract}
Economic geographies of Asia are highly fascinating, not the least because Asia has increasingly emerged as a significant economic player in all spheres of global competition: production, consumption, and circulation. This dynamic mosaic of economic landscapes in Asia was further complicated during the 1997-1998 economic crisis and thereafter. While some aspects of these economic geographies of Asia have already received research attention, many complex economic geographic processes in Asia have been undertheorized in the literature. This agenda-setting article makes two critical observations. First, the theorization of dynamic economic changes in Asia needs to be more critical of economic geography theories developed elsewhere in the Anglo-American context. The Asian case may significantly challenge existing theories in economic geography. Second, certain geographic processes in Asia require fundamentally new approaches to theorization that may contribute to the development of broader theories in economic geography. The economic dynamism of Asia has provided a useful site for the development of theory and empirical understanding in contemporary economic geography. To support our arguments and observations, we discuss the situatedness and specificity of influential theories of economic geography and offer some constructive suggestions for an intellectual agenda for developing new theories in economic geography.
\end{abstract}

Key words: economic geography, Asia, theory, epistemology, intellectual agenda.

The articles in this special issue originated in a special session held at the 98th annual meeting of the Association of American Geographers, Los Angeles, 19-23 March 2002. We thank Fulong Wu for coorganizing the session and all presenters for their participation. The submitted papers went through a rigorous review process and different rounds of revisions. We are grateful to the authors, numerous reviewers, and editorial board members for their cooperation and hard work in putting this issue together. An earlier version of this introductory article was presented as a keynote address at the annual meeting of the Canadian Association of Geographers, Toronto, Canada, 29 May-1 June 2002. Henry Yeung thanks Philip Kelly and Glen Norcliffe for their kind invitation to attend this conference and the CAG Study Group on Social and Economic Change for funding his travel. David Edgington, the paper's discussant, provided useful comments. We also received helpful comments from David Angel, Tim Bunnell, and Adrian Smith. This article was subsequently presented to various audiences in the United Kingdom and we owe a great deal to insightful comments from the participants: Raymond Bryant, David Demeritt, Chris Hamnett, Keith Hoggart, and Geoff Wilson, of King's College London; Ash Amin, Emma Mawdsley, Joe Painter, and Janet Townsend, of the University of Durham; and Clive Barnett, Keith Bassett, Tony Hoare, Simon Naylor, Nigel Thrift, and Adam Tickell, of the University of Bristol. While we have incorporated their comments as much as possible into this version, none of these institutions and individuals should be responsible for any shortcomings of this article. 
For a long time economic geographers have almost taken for granted that theories emerging from geographic studies of Silicon Valley or the City of London have been naturalized unequivocally as what may be termed "mainstream economic geography" - the influential core of Anglo-American economic geography. ${ }^{1}$ One needs only to glance through recent major collections of economic geography published in English (e.g., Bryson, Henry, Keeble, and Martin 1999; Clark, Feldman, and Gertler 2000; Sheppard and Barnes 2000) to reinforce the point that an overwhelming majority of the chapters tend to address theoretical and empirical issues specific to only a handful of advanced industrialized economies (see Yeung 2002a). This heavy concentration of economic geography theories in relation to their sites of production and dissemination has certainly shaped the directions of research in economic geography in many other countries and/or regions, albeit each at a different pace of diffusion and adoption. Studies of economic geography of other localities have not only tended to follow the "templates" that have been institutionalized and legitimized by this mainstream economic geography, but also have earned the strange title as some kind of "regional geography." In this vein, geographic research on industrial locations in China and export-

\footnotetext{
${ }^{1}$ We use the term economic geography to refer to a discipline that deals with "the nature of world areas in their direct influence upon the production of commodities and the movement of goods" (Gotz, quoted in Barnes 2001c, 531) or what Scott $(2000,484)$ described as "the spatial and locational foundations of economic life.” Economic geography supposedly has a wide spectrum of subjects, ranging from agrarian and pastoral economies to resource utilization and changes in land use. However, we have observed that major theoretical advancements in economic geography in recent decades have been overwhelmingly focused on the transformation of industrial economies in North America and Western Europe. We propose that economic geographers need to move forward along the lines of reconstructing a kind of global economic geographies that are broader in perspective and more inclusive in both sectoral and geographic terms.
}

processing zones in Malaysia is often labeled as "Asian geography"; studies of the informal sector in Africa, as "African geography"; and investigations of gender relations in Latin American labor markets, as "Latin American geography." Potter (2001, 423; original italics) vividly described this bias in economic geography as follows:

Those who work outside the Euro-North American orbit are excluded, or at best marginalized, from the specialisms which see themselves making up the core of the discipline of Geography. Quite simply, they are regarded as "ists" of the Latin American, Caribbean, African or Asian variety. If they endeavour to be comprehensive in their consideration of other regions of the globe, then they may qualify as the ultimate "ists": as full-blown "developmentalists"!

Such geographic specificity in constructing both leading theories in economic geography and the "other geographies" or "distant geographies" perhaps should not be surprising in light of the institutionalization of geography as an academic discipline (see Johnston 1997; Barnes 2000; Scott 2000). Few economic geographers have attempted to contextualize this specificity in the epistemology of economic geography and to offer suggestions for what may be done to redress it (see Yeung 2001a; Olds and Poon 2002; Smith 2002). In this article, we focus on a particular historicalgeographic moment- the rise of Asia - and outline our vision for the development of theory in economic geography emanating from a rapidly growing number of geographers working on the dynamic economic transformations of Asia. We term this effort "theorizing economic geographies of Asia." The plurality of the term represents a deliberate attempt to theorize the diverse experiences and trajectories of economic transformations in Asia. There is thus no singular economic geography of Asia but, rather, multiple pathways and diversities. By the same token, there should be many models and theories of these transformations in economic geography. 
This article has two interrelated aims. First, we offer a brief critique of leading theoretical perspectives in Anglo-American economic geography. We identify their inherent limits in relation to their analytical focus on historically and geographically specific industrial transformations. Second, we outline our advocacy for more theorization in future research on economic geographies of Asia. In steering the direction and content of this special issue, we were particularly driven by two concurrent trends - one intellectual and another empirical-that we believe will powerfully shape the future of economic geography. On the intellectual front, our efforts and that of the contributors to this special issue echo the recent institutional turn in economic geography from nationalistic economic geography to global economic geographies. Traditional economic geography has been concerned mainly with explaining patterns and processes within national space-economies. When such work is done within the AngloAmerican countries, the subsequent models and theories are deemed universally true and applicable. More recently, however, an increasing number of economic geographers have begun to question seriously the situatedness of theories and knowledge of the global economy. This new kind of economic geography has become much more inclusive and open to ideas and opinions conceived outside a few dominant cores. This turn clearly supports Taylor's (1996) broader call for abandoning the "embedded statism" in the social sciences to open up to the new intellectual spaces of global economic geographies. It is interesting to note that this opening up in geography has been well recognized by scholars from other social scientific disciplines. For example, political theorist Martin Shaw (2000, 73-74; original italics) argued, in the context of geography's role in globalization debates, that

[t]he disciplines of anthropology, geography and international relations have shown greater openness to global understanding than economics, politics and sociology, the histor- ically defining fields of social science. Interestingly, the former are all fields in which historically the national-international nexus was formerly not just a methodological bias, but more or less explicitly constitutive. The openness of both social anthropology and geography to globalization debates follows their abandonment of nineteenth- and early twentieth-century nationalist and imperialist constructions of their subjects. These subjects underwent theoretical and ideological transformations earlier in the post-war period, which have prepared the way for the recognition of globalization.

In redressing the thematic (industrial) and geographic (Anglo-American) specificity in mainstream theories of economic geography, we aim to develop what Slater $(1999,67)$ called "reverse discourses" in order for nonWestern work to "theorize back" at the West. These discourses should constitute "counterposed imaginations and visions emanating from different sites of experience and subjectivity." Similarly, Appadurai (1999, 237) argued for a conversation about and an imagination of research "to which scholars from other societies and traditions of inquiry could bring their own ideas about what counts as new knowledge and about what communities of judgment and accountability they might judge to be central in the pursuit of such knowledge."

This last point relates to the second concurrent trend in the empirical realm that has made the economic geographies of Asia highly fascinating. Asia has increasingly emerged as a significant economic player in different spheres of global competition: production, consumption, and circulation. This dynamic mosaic of economic landscapes in Asia was further complicated during the 1997-1998 economic crisis and afterward. Although some aspects of these economic geographies of Asia have already received research attention, many complex economic geographic processes in Asia have been undertheorized in the geographic literature, which leads to two important possibilities for future research. First, the theorization of dynamic economic changes in Asia needs to be more critical in adopting economic 
geography theories developed elsewhere in the Anglo-American context. As shown in the four articles in this special issue, the "Asian" case can significantly challenge existing theories in mainstream economic geography. Second, the economic dynamism and geographic processes in Asia require a fundamentally new approach to theorization that may contribute to the development of broader theories in economic geography. Through this process, we may witness the emergence of new kinds of theories that can account for differences and differentiation in global economic geographies - the distinguishing theme of economic geography reemphasized by Clark, Feldman, and Gertler (2000).

In the remainder of this article, we discuss the situatedness of mainstream theories of economic geography and show how Asia has been theorized in mainstream economic geography. We then examine how economic geographers may move from straightforward applications of "Western" theories in mainstream economic geography to the critical interrogation of these theories and the development of new theories through carefully grounded empirical research. We also offer some constructive suggestions for an intellectual agenda for developing new theories in economic geography.

\section{Geographies of Economic Geography: The Situatedness of Theories}

We have now been well told by historians of economic geography that dominant theories have always emerged from particular historical and geographic contexts (see Barnes 1996; Scott 2000). From locational models to spatial divisions of labor and from flexible specialization to local embeddedness, leading theories of economic geography have their peculiar histories and geographies. Their histories are very much outcomes of the conscious efforts of individual economic geographers in the context of creative tensions among different "paradigms" (see Barnes and Curry 1983; Sidaway 1997; Thrift and Walling 2000; Barnes 2001b). In this and the next sections, we attempt to answer two related questions to explore further the situatedness of dominant theories in economic geography. First, why are economic geography theories, from the quantitative revolution and Marxism to flexible specialization and the recent "cultural turn," so dominant as if they were universal theories capable of explaining diverse economic geographic processes? Yet, why are they so little used in the economic geographic studies of other regions? Second, why have theoretical insights that have emerged from area studies and regional geography failed so far to capture the imaginations of mainstream economic geographers?

There is a noticeable gap between the obsession of some mainstream economic geographers with the universalization of their Western-based theories and the preoccupation of regional geographers with the task of meticulously sorting out the geographic specificities of particular countries or regions. We argue that this gap has been the consequence of historically specific circumstances, including the legacy of earlier colonialism, or what Hudson (1977, 12) referred to as the interests of European and American imperialism in world commerce and territorial acquisition (see also Barnes 2001c, 530); provincialism during and after the Vietnam War; linguistic and cultural barriers; and an intellectual environment that was dominated, until recently, by the Enlightenment and modernization school of thought. The persistence of this bifurcation in epistemology and methodology has led to the phenomenon of "the tragedy of the commons" in economic geographytheories that are derived from specific historical geographies become universalized among the former group of economic geographers, and descriptive specificities of regional geographies have little generality to offer to geographic studies in other countries and/or regions. We believe that such a tragedy of the commons has severely hindered the growth of a new kind of economic geography, known as global 
economic geographies, that must be built on comparative understandings of economic geographic processes emerging from and interconnecting different regions of the global economy.

In Table 1, we summarize several leading theoretical perspectives in mainstream economic geography that rose to prominence during the past two decades or so.
In constructing this table, we did not intend to "fit" different economic geography theories (and their proponents) into specific boxes. Rather, the table should be read as a heuristic device for the purpose of this article. Furthermore, we did not intend the table or the finality and "paradigmatic" nature of these theoretical themes to be complete and all-inclusive. We regret that

\section{Table 1}

Leading Theoretical Perspectives in Economic Geography and Their Historical Geographies

\begin{tabular}{|c|c|c|c|}
\hline Theoretical Perspectives & Period of Prominence & Key Authors & $\begin{array}{c}\text { Geographic Specificities } \\
\text { of Research }\end{array}$ \\
\hline $\begin{array}{l}\text { 1. Location theory and the } \\
\text { behavioral location model }\end{array}$ & $1960 s-1970 s$ & $\begin{array}{l}\text { Brian Berry } \\
\text { Peter Haggett } \\
\text { Peter Dicken } \\
\text { F. E. I. Hamilton }\end{array}$ & $\begin{array}{l}\text { United States } \\
\text { United Kingdom }\end{array}$ \\
\hline 2. Spatial divisions of labor & $1980 \mathrm{~s}$ & $\begin{array}{l}\text { Doreen Massey } \\
\text { Gordon Clark }\end{array}$ & $\begin{array}{l}\text { United Kingdom } \\
\text { United States }\end{array}$ \\
\hline $\begin{array}{l}\text { 3. Flexible specialization and } \\
\text { new industrial spaces }\end{array}$ & $1980 s-1990 s$ & $\begin{array}{l}\text { Allen Scott } \\
\text { Michael Storper } \\
\text { David Harvey } \\
\text { Richard Florida } \\
\text { Meric Gertler } \\
\text { Andrew Sayer }\end{array}$ & $\begin{array}{l}\text { United States } \\
\text { Italy } \\
\text { Germany }\end{array}$ \\
\hline $\begin{array}{l}\text { 4. Networks and embedded- } \\
\text { ness }\end{array}$ & $1990 \mathrm{~s}$ & $\begin{array}{l}\text { Nigel Thrift } \\
\text { Peter Dicken } \\
\text { Gernot Grabher } \\
\text { Philip Cooke } \\
\text { Ash Amin }\end{array}$ & $\begin{array}{l}\text { United Kingdom } \\
\text { Europe }\end{array}$ \\
\hline $\begin{array}{l}\text { 5. Regional agglomerations } \\
\text { and clusters }\end{array}$ & mid-1990s & $\begin{array}{l}\text { Michael Storper } \\
\text { Allen Scott } \\
\text { Philip Cooke } \\
\text { Kevin Morgan } \\
\text { Anders Malmberg } \\
\text { Peter Maskell } \\
\text { Ray Hudson } \\
\text { John Lovering }\end{array}$ & $\begin{array}{l}\text { United States } \\
\text { United Kingdom } \\
\text { Europe }\end{array}$ \\
\hline $\begin{array}{l}\text { 6. Regulation theory and } \\
\text { governance }\end{array}$ & mid-1990s & $\begin{array}{l}\text { Jamie Peck } \\
\text { Adam Tickell } \\
\text { Erik Swyngedouw }\end{array}$ & $\begin{array}{l}\text { France } \\
\text { United Kingdom } \\
\text { Europe }\end{array}$ \\
\hline 7. Cultural economies & mid-1990s & $\begin{array}{l}\text { Nigel Thrift } \\
\text { Ash Amin } \\
\text { Erica Schoenberger } \\
\text { Linda McDowell } \\
\text { Trevor Barnes } \\
\text { J.-K. Gibson-Graham } \\
\text { Roger Lee } \\
\text { Jane Wills }\end{array}$ & $\begin{array}{l}\text { United Kingdom } \\
\text { United States } \\
\text { and Canada } \\
\text { (to a lesser extent) }\end{array}$ \\
\hline
\end{tabular}


certain key histories of (mainstream) economic geography have not been included in this table and the text. For example, one may notice that most theoretical perspectives in Table 1 deal with industries, rather than rural economies, natural resources and land use, financial markets, development processes, and so on. Yet largely for reasons suggested later, these theoretical perspectives are the most influential in contemporary economic geography as if they constitute the core of economic geography. Although a full critique of this industrial bias in contemporary economic geography is beyond the scope of this article, it is clear that even within Anglo-American economic geography, there is a significant marginalization of research into spheres of economic activities other than industries. This observation, we believe, has a lot to do with the historical and geographic specificity of these theoretical perspectives.

Bearing in mind these caveats, we point out that none of the major proponents of these theories of economic geography originated from outside the Anglo-American countries. Neither do most of them conduct their empirical research outside these advanced industrialized economies. This sweeping generalization points to the geographic specificities of these leading or dominant theories - they have been really leading and dominant among Englishspeaking economic geographers (see also Olds and Poon 2002). Location theory, for example, originates from what Barnes (2001a, 546) termed "epistemological theorizing," which assumes "that spatial economic phenomena could be expressed in an explicitly abstract, formal, and rationalist vocabulary and directly connected to the empirical world." This assumption allows for location theory to be universally generalizable from one geographic site to another. We should therefore expect it to be well applied in research on the economic geography of Asia. The reality, however, seems to work on the contrary. With the exception of G. William Skinner's (1964) influential work on marketing and social structure in rural China (see Cartier 2001 for a critique), much of the research in economic geography in Asia during the 1960s and the 1970s remained descriptive and aligned with area studies and regional geography (Spencer 1954; Spate and Learmonth 1967; Ginsburg and Brush 1958; McGee 1967; Wheatley 1971; Murphey 1953; McGee and Yeung 1977).

Subsequent critiques of location theory and its variant in the behavioral locational model by such radical economic geographers as Massey $(1973,1984)$ and Walker and Storper (1981) led to the development of alternative theories on how to explain spatial economic phenomena. On the basis of their empirical studies of (de)industrialization in the United Kingdom and the United States, Clark (1981), Massey (1984), and Storper and Walker (1989) arrived at their respective theories of spatial divisions of labor and spatial switching by capital (see Table 1). These theories attempted to explain why (de)industrialization occurred in some but not all regions in the United Kingdom and the United States. The objective of the project was to specify the interdependent links between social processes of capitalist production and the spatial structures and distribution of industry, work, and classes. Although these theoretical perspectives on spatial divisions of labor generated much heated and exciting debates in subsequent studies of industrial restructuring and specific localities, most of these studies remained grounded in the industrial landscapes of the Anglo-American countries. Given their prominence in the mainstream economic geography of the 1980s, we would expect these perspectives to be universally applied to other research and empirical contexts. To the best of our knowledge, however, there has not been a significant diffusion of these theories of economic geography to geographic studies of other regions and countries that are concurrently experiencing dramatic processes of industrialization, economic restructuring, and rural development. This observation is certainly applicable to studies of the economic geography of Asia, although it is equally interesting to note that some Asian 
economies experienced unprecedented processes of industrialization during exactly the same periods - the 1970s and the 1980s. Mainstream economic geography thus fails to extend its analytical lens to examine geographic industrialization-let alone other aspects of economic transformations (e.g., rural changes and deprivation)-in other developing regions of the world economy. In the next section we outline what theoretical insights emerged from other social scientific studies of industrialization in Asia during these two decades.

Into the 1990s, mainstream economic geography certainly experienced a kind of intellectual renaissance through which a plethora of complementary theoretical perspectives were proposed-flexible specialization, networks and embeddedness, agglomerations and clusters, and regulation and governance. As is summarized in Table 1 , these perspectives were concerned with why certain territorial ensembleswhether regions or new industrial spacesemerged as the motors of growth in a particular country. It is no historical coincidence that during the late 1980s and the 1990s, several regions in the United States and some European economies became the leading engines of growth in the global economy. These theories vividly mirrored the historical and geographic specificities of the global space-economy. On the basis of his empirical analysis of the growth of high-tech industries in California, Italy, and France, Scott (1988) argued that a major shift was under way in contemporary capitalist industries-from mass production of the Fordist kind toward a post-Fordist form of flexible specialization and customization of production. These highly geographically specific observations led Scott (1988, 4; original italics) to conclude that "a series of new industrial spaces had come into existence and were beginning to form important alternative centers of capitalist accumulation based on a strong social division of labor, proliferations of small to medium-sized industrial establishments, and the marked reagglomeration of production." Although Scott's conclusions were not entirely new vis-á-vis Piore and Sabel's (1984) earlier study of the Second Industrial Divide, his arguments for the rise of new industrial spaces did make a major impact on research in economic geography up to the mid-1990s (see a review in Yeung 1994).

New theoretical insights were also required to explain the geographic organization of production through firms and networks in these so-called new industrial spaces. Geographic agglomeration, proximity, processes of tacit knowledge and learning, and cooperative networks were conceptual categories proposed within this genre of theoretical and empirical research that has come to dominate much of AngloAmerican economic geography since the late 1980s. More recent theoretical work on "relational assets," agglomeration economies, and institutional governance in the United Kingdom and the United States has reinforced the resurgence of the "regional world" of production as the dominant research theme in mainstream economic geography (see Yeung 2000). This resurgence, however, must again be situated in its peculiar historical and geographic contexts. Flexible production methods and agglomeration economies have been in existence for centuries, as found in craft industries and so on. The rise of these production methods and geographic economies to intellectual prominence within Anglo-American economic geography must have something to do with the "crisis of Fordism" during which an earlier wave of methods of mass production and economies of scale could no longer maintain a competitive edge with incumbent firms and corporations in advanced industrialized economies. This crisis, nevertheless, can also be understood from the historical perspective of the immense Japanese challenge to AngloAmerican industrial might during the late 1970s and the 1980s (see the next section). These new theories of economic geography thus emerged as an unintended response to historical urgency-to explain the downfall of Fordist firms and industries and the rise of new propulsive industries (e.g., in Silicon Valley and elsewhere). 
An important question remains: why did not these important and innovative theories in economic geography emerge from research on Fordism's competitors-Japan and the newly industrialized economies (NIEs) in Asia? Why did we not have economic geography theories that examined the crisis of Fordism and the rise of new industrial spaces in relation to the growing economic might of Japan and the NIEs? We return to this question in the next section.

The geographic context of these theories in economic geography is equally intriguing. Two observations are critical here. First, most theoretical work was based on empirical studies of a few selected regions in advanced industrialized economies in the United States (e.g., Silicon Valley and Route 128) and Europe (e.g., the M4 corridor and Cambridge, in the United Kingdom, the Third Italy, Baden-Württemberg in Germany, and the Scientific City in France). This spatial selectivity of empirical cases places an upper limit on the applicability of these theories even to different regions of the same country, let alone countries with contrasting forms of capitalism (Clegg and Redding 1990; Whitley 1999; Stark and Bruszt 2001). The geographic specificity of these theories explains why certain (propulsive) industries are privileged in their explanatory matrixes and why other important issues in economic geography are sidestepped. While flexible specialization may be crucial to understanding the economic transformation of the United States during the 1980s, one may surely argue that the transformation of agrarian economies under the auspices of neoliberal economic policies may be equally significant to the economic geographic understanding of many developing economies. We do not deny that a less-visible community of economic geographers, or those who have been branded as "development geographers" by the mainstream, have been studying the latter phenomenon. But their influence in economic geography remains limited precisely because mainstream economic geographers during the past two decades were narrowly focusing on a few industries and regions in a handful of advanced economies. Second and relatedly, most leading proponents of these theories come from a few prestigious research departments in the United States and the United Kingdom. This geographic situatedness of authorship does not automatically invalidate the general applicability of their theories. But it does explain why certain theories emerge and become influential through more intensive interactions among likeminded scholars and research activities in these institutions. Their applicability to other geographic contexts needs to be interrogated and validated through carefully designed empirical research (see the articles in this special issue).

The situatedness of theories of economic geography is perhaps best illustrated by the recent "cultural turn" in economic geography toward a kind of "new economic geographies" that is much more reflexive and open in its nature and subject matter (Thrift and Olds 1996; Lee and Wills 1997; Yeung forthcoming). Indeed, Thrift and Olds $(1996,313)$ argued that we need to "make a space for new kinds of economic geography that can supplement or even replace the older forms of economic geography." In this process, Wills and Lee (1997, xvii) stated, we must appreciate how to "contextualize rather than to undermine the economic, by locating it within the cultural, social and political relations through which it takes on meaning and direction." According to Barnes (2001a, 551), this mode of "hermeneutic theorizing" differs significantly from the "epistemological theorizing" manifested in the quantitative revolution because it "[1] rejects fixed and final foundations ... . [2] promotes experimentation and engagement with radically different vocabularies, pressing them as far as they will go . . . [3] cultivates critical self-awareness of social and historical location and recognizes its influence on knowledge ... . [and] [4] is interested in keeping the conversation going." Precisely because of the inherent reflexivity and openness in the new economic geographies, it is very difficult to summarize diverse strands of theories and empirical findings. At the 
least, new economic geographers have refigured the economic through an excursion into the cultural and the political. As Barnes $(1999,17)$ noted, the basic explanatory categories become "social power, cultural identity and institutional situatedness rather than economic ownership, universal definitions and individual agency." Several features of the new economic geographies include understanding the social embeddedness of economic action, mapping shifting identities of economic actors, and exploring the role of context in explaining economic behavior (see a review in Barnes 2001a; Yeung 2001b; forthcoming).

To sum up our sympathetic critique, mainstream economic geography, which was developed in the Anglo-American countries, has experienced tremendous internal transformations and metamorphism during the past four decades. Its theoretical core has moved from universalizing location theory during the quantitative revolution to geographically specific theories of territorial development during the 1980s and the 1990s and, recently, to the more reflexive cultural turn that champions heightened sensitivity to the positionality of knowledge and theories and the context in which these theories emerge. This unprecedented intellectual movement in the epistemology of economic geography provides an exciting and important opportunity for us to reconsider what theories of economic geography may be if we situate these theories in specific regions beyond the Anglo-American countries (see the articles in this issue). More significant, we may have arrived at a time when new kinds of theories of economic geography are needed to account for the diversity of experience and transformations in the global economy. In this way, we may be able to construct genuine global economic geographies that are attuned to the historical and geographic specificities of our theories and yet are capable of producing a much broader and comparative understanding of dramatic economic transformations in the new millennium. Before we theorize the economic geographies of Asia, it is impor- tant for us to situate the region in the emerging global economic geographies.

\section{Situating Asia in Global Economic Geographies}

As a prelude to our advocacy, we argue that if we look seriously beyond North America and Western Europe, we can undoubtedly find innovative theoretical insights from social science studies of other regions. Although these theoretical insights are no less historically and geographically specific than those championed in mainstream economic geography, few have really originated from the work of economic geographers or human geographers in general. Instead, these theoretical insights have emerged mostly from developmental studies, anthropology and sociology, and political economy. The situated nature of theoretical insights gathered from intensive studies of specific countries and/or regions should not be surprising if we take theories as hermeneutics or discursive formations that must be firmly grounded in material realities. These realities, however, differ from one historical moment to another and from one geographic setting to another. For example, whereas studies of Latin America have given rise to dependency theory, social science studies of Asia have similarly generated many important theoretical insights, some of which have been followed up in the recent literature on economic geography: (1) the flying geese hypothesis (HartLandsberg and Burkett 1998; Edgington and Hayter 2000); (2) the new international division of labor (Frobel, Heinrichs, and Kreye 1980; Henderson 1989); (3) the developmental state (Douglass 1994; Clark and Kim 1995; Brohman 1996; B.-G. Park 1998; Yeung 1999; Hsu and Cheng 2002); (4) social capital (Leung 1993; Hsing 1998; Yeung 1998c; Olds 2001a); and, more recently, (5) transnationalism (Mitchell 1995; Olds and Yeung 1999; Ley 1999; Hsu and Saxenian 2000; Yeoh and Chang 2001; Zhou and Tseng 2001; G. C. S. Lin 2002a; Ma and Cartier 2003). 
It is important to note, however, that in stark contrast to such theories as spatial divisions of labor and flexible specialization, these theoretical interrogations that are grounded in Asia have not yet made a significant impact on the development of mainstream economic geography described in the previous section. Instead, mainstream economic geography produces the "right" kind of theories, emanating from specific cases in the Anglo-American countries that remain to be tested as universal principles that are equally applicable to other, more marginal, regions of the global economy. Economic geographers fail to heed Appadurai's (1999, 230) telling warning, in the context of area studies, that "the more marginal regions of the world are not simply producers of data for the theory mills of the North." How, then, has this highly unequal division of labor in research on economic geography emerged? We analyze this phenomenon in relation to three groups of geographers: (1) those who have engaged in mainstream enquiry, (2) those who have engaged in area studies, and (3) those who have interrogated mainstream theories on the basis of the Asian experience.

Historically, Asia - just like Africa, Russia, and Eastern Europe-has never really attracted serious attention in mainstream economic geography, despite the discipline's celebrated interest in spatial differentiation and uneven development. Even if it did, Asia was treated as "the others" in "the Far East," previously a market to be opened up by colonialism and now posing a challenge to the industrial might in Europe and North America (see Amsden 2001). This tendency toward what Said (1978) termed "Orientalism" is no less significant in economic geography than in the humanities and the other social sciences. The real difference, however, rests with the fact that Asia, along with Africa and Latin America, has been well studied by development specialists outside mainstream economic geography. Development is clearly central to the studies of economic geography and has always been one of the most exciting topics to university students of economic geography in North America and Western Europe. Ironically, development geography has been largely constituted outside mainstream economic geography, in which overwhelming attention was devoted to industrial transformation in a few advanced economies and/or regions. This tension between development geography and economic geography has effectively marginalized, if not excluded, Asia on the research agenda of economic geography.

Meanwhile, the empirical landscape of Asia has undergone dramatic transformations since the 1970s, when Japan began to emerge as the leading competitor and alternative to the Anglo-American model of industrial capitalism. Ezra Vogel's (1979) influential book Japan as Number One was widely circulated in major intellectual and policy circles (that are often based in Washington, D.C., or the two Cambridgesone in England and the other in New England). Coupled with the emergence of Asian NIEs and the 1973 oil crisis, the rise of Japan triggered what was later conceptualized as flexibility, post-Fordism, and globalization. It is interesting that the social scientists who first realized the indispensable role of Japan and Asia in their theorization of global economic change came largely from area studies (Vogel 1989; Frank 1998), political science (Johnson 1982; Amsden 1989; Wade 1990), and economic sociology (Hamilton and Biggart 1988; Redding 1990).

More specifically, Japan was significantly featured in Piore and Sabel's (1984) The Second Industrial Divide and Womack, Jones, and Roos's (1990) The Machines That Changed the World. Both MIT (Cambridge, Mass.) products have fundamentally shaped the subsequent debates about America's and, by extension, the world's industrial future. During the same period (the 1980s and early 1990s), flexible specialization attracted substantial attention from economic geographers (see Table 1). As we noted earlier, much of this work was inspired by empirical studies in California, the Third Italy, and other European regions, with limited applicability to the Asian context (see Patchell 
1993a, 1993b; Eng 1997). In comparison with other major social sciences and with a few exceptions (e.g., Dicken 2003; Florida and Kenney 1990; Angel 1994), mainstream economic geography has certainly missed the boat in exerting its intellectual influence on major policy debates in the United States and Europe about the imminent economic challenge from Asia and elsewhere (cf. Reich 1991; Tyson 1993; World Bank 1993).

Vogel's influential warning in Japan as Number One, nevertheless, was short lived. With the downturn of the Japanese economy since the early 1990s and the Asian financial crisis during 1997-1998, few people now take seriously "the Asian miracles" and the dawn of "the Asian century." In deconstructing "the myth of the Asian miracles" and the recent Asian economic crisis, mainstream economic geographers once again have failed to assume intellectual leadership in the broader social sciences. Curiously, it is the economists and their political science counterparts who have spearheaded the debates about the downfall of Japan, the Asian economic crisis (Krugman 1994, 1998; Radelet and Sachs 1998; Wade and Veneroso 1998), and the alleged rise of China as a threat (Vogel 1989; Goodhart and Xu 1996; Gertz 2000). Asking "Where have all the geographers gone?," Kelly, Olds, and Yeung (2001, x-xi) noted the absence of economic geographers in debates on the origins and impact of the Asian economic crisis. This lacuna is unfortunate because the crisis has much to offer to our understanding of the destabilization of a global financial architecture that is essentially built on the Bretton Woods institutions. The sheer scale and scope of the crisis also provided a unique case for reworking the fundamental nature and future of global capitalism and its powerful institutions (see Stiglitz and Yusuf 2001; Wade 2002).

If mainstream economic geography cannot contribute much to our understanding of the complex economic landscapes of Asia (other than making available situated theories for superficial testing and straightforward applications elsewhere), can we turn to area studies specialists (often known as development geographers), who may offer such an understanding from a more grounded perspective? Asia has long been studied by human and economic geographers who are interested in what cultural anthropologist Geertz (1973) termed a "thick description" of the land and the people outside Europe and North America. These geographers include indigenous scholars living in the regions and Western scholars who are interested in Asia. The former group has as sizable a population as their counterpart in Western Europe and North America. For instance, in the 1970s, over 6,000 professional geographers were working and teaching in socialist China, a size similar to if not greater than that in the United States (Pannell 1980, 176). Today, these Chinese professional geographers are all fulltime researchers or university professors on the payroll of the state. Unfortunately, indigenous geographers in Asian countries have never been able to make any significant impact on mainstream enquiry in economic geography, largely because of the linguistic and cultural barriers as well as their different methodological traditions that have severely hindered meaningful scholarly exchanges with mainstream economic geographers. On the other hand, Western scholars who are interested in Asia have been in the minority, preoccupied with sorting out the facts about a mysterious region in the "Far East" for the occasional curiosity of Western academics and continuous strategic and economic interests.

With the exception of perhaps the flying geese model, studies of the economic geography of Japan have never occupied any prime position equivalent to the global significance of its national economy-not even in the flexible-specialization debate of the late 1980s and early 1990s. ${ }^{2}$ Geographic studies of China and India, whose combined

\footnotetext{
${ }^{2}$ We regret that no article on Japan is included in this special issue, primarily because of insufficient submissions. See recent work by Peck and Miyamachi (1994), Aoyama (2000), and Patchell (2002).
} 
population constitutes nearly half the people of the world, have not generated research published in English-language media that is anywhere near the global significance of their population (see also Potter 2001). A systematic search of articles published in the top 10 international journals in human geography from 1971 to 2000 found that only 66 articles, less than 1 percent of the total, dealt with the geography of China (G. C. S. Lin 2002b, 1813). Most of these studies were empirical and "had shallow roots, received little nourishment and predictably bore few and unappetizing fruits" (Leeming 1980, 218). It has only been recently that geographers who are interested in China have ventured to formulate some contextually sensitive theories (Fan, Ma, Pannell, and Tan forthcoming). The article by Yu Zhou and Tong Xin in this special issue thus significantly contributes to the critique of the literature on innovative regions that has primarily focused on localized endogenous factors in sustaining innovation and regional development. Through their intensive research in a high-tech cluster in Beijing, Zhou and Xin found important interactive and interdependent relations between local Chinese firms and global corporations in the joint development and commercialization of new information technologies. Their work complements the growing literature in economic geography on the critical importance of nonlocal and decentralized learning and innovations for understanding regional development (e.g., Bunnell and Coe 2001; MacKinnon, Cumbers, and Chapman 2002).

A relatively small group of geographers have managed to develop original theoretical insights from their grounded studies of the Asian experience. Through their work, some grounded theories have emerged that have proved to be influential in certain subfields of human geography and, to a lesser extent, economic geography. A prominent example of such grounded theories is Terry McGee's $(1967,1971)$ model of the Southeast Asian city (see also Armstrong and McGee 1985). In this morphological model of the internal structure of the city, McGee argued that different urban-economic activ- ities have different spatial requirements and locational characteristics. For example, the informal sector tends to be located in the inner ring of the city. McGee's model has subsequently been well applied to the geographic study of other Third World cities. More crucially, it originated from empirical studies of such cities; it was not developed from studying the internal structures of advanced industrialized countries and then applied universally to Third World cities (akin to "epistemological theorizing" described earlier). Despite its generality in studies of urbanization and urban economic activities, McGee's model regrettably had only a limited impact on mainstream economic geography of the 1970s and 1980s, which was preoccupied with radical Marxism and post-Fordism.

More recently, geographic studies of transnational business activities and transnationalism represent a significant attempt to bring grounded theories of economic geographies of Asia back into mainstream economic geography (Leung 1993; Mitchell 1995; Yeung 1997; Zhou 1998; Hsu and Saxenian 2000; Olds 2001a). In particular, this body of literature on economic geography has managed to blend into its theoretical framework two important ingredients-a special blend that is well grounded in the Asian context. First, it has brought to its analytical forefront the conceptual lenses of networks and embeddedness. Although these conceptual categories did not originate from economic geographic studies of Asia, it is equally important to note that mainstream economic geographers did not develop them either. Indeed, these conceptual categories were first proposed by economic sociologists (Polanyi 1944; Granovetter 1985) and subsequently introduced into and appropriated by mainstream economic geography during the debate on flexible specialization (see Dicken and Thrift 1992). It is true that mainstream economic geography has further enhanced the theoretical sophistication of both conceptual categories through major debates on industrial districts (Asheim 2000), the spatial transfer of technologies (Gertler 2001), organizational change (Yeung 1994, 
1998a; Schoenberger 1997), and institutionalism in urban and regional development (Amin 1999). But then it must be equally valid to argue that economic geographic studies of Asia during the 1990s significantly advanced the spatialization of these conceptual categories by theorizing the complex interactions among business networks, ethnicity/culture, embeddedness, and historical specificity. This effort to theorize the spatial rudiments of networks and embeddedness is no less significant than that of debates on industrial districts and so on (see Table 1).

Second, economic geographic studies of Asian diasporas and their worldwide webs in Europe and North America have made significant inroads into the debate on globalization. In many ways, this body of literature has contributed to enhancing economic geography's growing visibility in social scientific debates on globalization. Once again, geographers have not been well represented among leading scholars of globalization: one can literally think of only two works by geographers-Peter Dicken's (2003) Global Shift and David Harvey's (1989) The Condition of Postmodernity - that have represented different kinds of geographic takes on globalization and thereby have attracted different sorts of audiences. Economic geographers, however, have something significant to say about the geographic specificities of globalization in relation to the origins, processes, and outcomes of globalization (see Amin 1997; Yeung 1998b, 2002b; Kelly 1999; Peck and Yeung 2003). ${ }^{3}$ Put in this perspective, economic geography research on Asian diasporas and their global networks

\footnotetext{
${ }^{3}$ The recent special issue of Economic Geography (2002) on geographies of global economic change represents an important milestone in this endeavor to put geographers back on the intellectual table of globalization studies. The special issue originated from the 2001 Leir conference (http://www.clarku.edu/leir/index. shtml) funded by the U.S. National Science Foundation, to rethink how to build theories of geographies of global economic change and to unveil the theoretical and methodological obstacles to the process of theory building.
}

augments well the key mission of mainstream economic geography to ground globalization processes in specific territorial ensembles and formations. It helps not only to demystify the "faceless" representations of globalization by its ultra-supporters (e.g., Ohmae 1990), but also to make economic geographers aware of the highly uneven geographic outcomes of processes associated with globalization. To us, this geographic research on the globalization of Asia is worth as much intellectual capital as is other equally worthy research on globalization in economic geography on changing urban and regional governance (Brenner 1999) and the organizations of economic activities (Dicken, Kelly, Olds, and Yeung 2001).

\section{Theories Wanted! An Intellectual Agenda for Economic Geographies of Asia}

We are at a critical juncture in economic geography. There are unprecedented opportunities for mainstream economic geographers to give up our long-standing EuroAmerican-centric bias and develop theories that account for differences and differentiation in an era of accelerated globalization (cf. McGee 1991; Olds 2001b; Yeung 2001a). Although concerns about national security remain large, especially after the September 11, 2001, tragedy, earlier warped provincialism can no longer inhibit economic geographers who actively study the rapid transformation of regional economies in Asia. Major funding agencies, such as the National Science Foundation in the United States, the Economic and Social Research Council in the United Kingdom, and the Social Sciences and Humanities Research Council in Canada, have recently supported a growing number of research projects on Asia. Many leading universities in AngloAmerica have actively recruited geographers to work on Asia. On the other side of the Pacific, most of the Asian economies have rearticulated themselves actively and openly to take part in the theater of global capital 
accumulation. Indigenous geographers in Asia have made special attempts to overcome linguistic and cultural barriers as they forge bilateral scholarly linkages and research collaborations with geographers in the English-speaking world. Intellectually, universalism as one of the defining features of the Enlightenment and modernization school of thought has given way to a more open-ended, plural, and contextually sensitive perspective on changing geographies in different world regions. Overall, the institutional setting that previously separated the regional geography of Asia from mainstream economic geography in the Anglo-American countries has undergone a profound transformation in a direction favorable to the development of global economic geographies.

Indeed, we are beginning to witness such a change in the direction of mainstream economic geography_more inclusive quality control in the academic production of knowledge and more intellectual activities organized outside the Anglo-American centers (see Barkema, 2001 for management studies). It is now incumbent on economic geographers who are interested in Asia to move from area studies to engage more actively with mainstream theoretical (re)constructions and interrogations. In this sense, there is a need for two intellectual movements. First, we must avoid uncritical applications of "Western" theories in mainstream economic geography as if these theories were universally true. We need to interrogate these theories critically through our detailed research on economic geographies of Asia. Through this process of critical engagement with mainstream theories, we will be able not only to contribute to economic geography through our refinement and reconstruction of these theories, but also to understand the economic landscapes of Asia from a grounded perspective. Second, we must turn away from doing what may be termed "Asian economic geography" because such a parochial approach to economic geographies of Asia will provide few significant theoretical insights that may be useful in other geographic contexts.
Rather, we must endeavor to develop new theories, grounded in Asia, that might better inform our understanding of the "economic" in economic geography at large. Commenting on management studies, Barkema $(2001,616)$ noted that " $[\mathrm{i}] \mathrm{f}$ different management concepts, theories, and practices apply in different cultural and institutional settings, international research might lead to novel theory and evidence showing how." In this sense, there should not be a "mainstream" economic geography on the basis of geographic divides (the Anglo-American centers versus the rest of the world) or thematic divides (industrial geography versus rural or development geography).

Why is such an intellectual turn toward more-inclusive global economic geographies necessary? As outlined briefly in the introduction, we believe that two important concurrent trends warrant this turn. The first trend is inevitably related to the globalization of knowledge and theories. Economic geographers from major Anglo-American centers are increasingly reaching out to Asia so that Asia can be integrated into their theories and comparative analyses. As we argue later in the empirical realm, Asia is becoming too important to be ignored by economic geographers; it is, of course, also too important to be left to economic geographers only. This interest in Asia is exemplified by the recent work on flexibility, globalization, social capital, the cultural turn, the institutional turn, and the relational turn in economic geography. There is a growing interest among economic geographers in investigating territorial formations outside the Anglo-American contexts not as an anomaly or "other economic geography" from the perspective of Anglo-American economic geography, but instead as an original subject of inquiry in its own right. In this special issue, Smart and Lee critically engage one major theoretical strand in recent work in economic geography — regulation theory (see Table 1). Analyzing the vital role of real estate and property assets in Hong Kong's regime of accumulation and economic development during the past two decades, Smart 
and Lee argue that the Hong Kong case should not be interpreted as an anomaly that deviates from the developmental trajectory of Anglo-American capitalism (see also Kerr 2002 for an analysis of Japan). The distinctive features of Hong Kong's regime of accumulation mean that it is indeed possible to "examine them as forerunners of a possible future property-based mode of regulation that might emerge in the West, and thus to diagnose the potential problems and opportunities of such a path" (Smart and Lee 2003, 153; our emphasis). This "theorizing back" does not entail an unproblematical application of Western-centric theories per se. Instead, it uses conceptual apparatuses in these theories and empirical evidence in Asia to open up new directions for understanding the future of a variety of capitalisms that, no doubt, include the dominant AngloAmerican genre.

This trend toward reaching out to Asia clearly does not represent a one-way flow in the globalization of knowledge and theories. Today, more economic geographers who are interested in Asia are themselves Asians who have received their academic training in the Anglo-American centers (e.g., both authors of this article and most contributors to this special issue). This two-way intellectual fertilization allows them to benefit from the best of both worlds, so to speak. On the one hand, their particular backgrounds and origins in Asia enable their work to be firmly grounded in the material realities of Asia. Their emic understanding of Asia is difficult to emulate by geographers from other regional origins. On the other hand, these geographers are well equipped with sophisticated theoretical ideas and rigorous methodological procedures to enhance their research on economic geographies of Asia. They are certainly capable of growing out of Asia in their theoretical work to make major contributions to global economic geographies. The articles in this special issue clearly exemplify this theoretical sophistication and methodological rigor among economic geographers with Asian origins. For example, in explaining the recent liberalization and globalization of the South Korean automobile industry, Park not only draws on theoretical ideas from the debate on the multiscalar processes of globalization, but makes an original contribution to the literature by highlighting the interscalar contestation between the national state and the local community in shaping the globalization processes of the industry. Although this national-local tension has been analyzed in the regional governance literature in economic geography (see Table 1 ), it has been mostly ignored in the geographic studies of the impact of globalization that have focused primarily on globallocal tensions. Similarly, Poon and Thompson examine rigorously the concept of embeddedness in explaining the parentsubsidiary relationship in global corporations. By unpacking the nature of the embeddedness of subsidiaries in the global networks of their parent companies, they draw our attention away from localized embeddedness that has been well documented in the "new regionalism" literature (see Table 1) and contribute to our understanding of the spatial organization of economic activities among global corporations.

What in Asia attracts these economic geographers such that Asia becomes their key subject of inquiry? Our answer lies with the empirical trend toward the rapid and dramatic transformations in the economic landscapes of Asia in more recent decades. Asia has become a new site for theory development and empirical analysis in economic geography, as amply shown by the four excellent articles in this special issue. The importance of this new site does not merely rest with its internal transformations. More crucially, Asia's importance for economic geography is predicated on its potential to facilitate the production of new theoretical insights and, in Slater's (1999) words, "counter discourses" that allow economic geographers to "theorize back" at our situated knowledge emanating from Europe and North America (e.g., Park, Smart and Lee, and Zhou and Tong in this issue). As we noted earlier, Japan came to the forefront of social scientific inquiry during the $1980 \mathrm{~s}$ because of its technological and economic 
prowess. Together with insights from other newly industrialized economies (except Hong Kong), research on Japan's rapid post-World War II economic development points to the role of the developmental state. From an economic geography perspective, this theorization allows economic geography to reconsider location theory and the development of industrial districts in novel ways that otherwise are unlikely to be achieved single-handedly through research on the Anglo-American countries (see Markusen and Park 1993; Park and Markusen 1995). It allows for the attainment of the "translocal" understanding and development advocated by Smith (2002). This movement in theorization entails more than just using different empirical contexts for theorization. Rather, it produces a new kind of theory that challenges, for example, the market-state dualism that is so ingrained in AngloAmerican economic thinking, particularly among the neoliberals and "deregulationists" as labeled by Storper and Salais (1997, 246).

The rise of China since the late 1970s represents another critical juncture in the historiography of economic geography. For decades, the transformation of the Chinese space-economy under socialist authoritarianism has often been considered to be too unique or peculiar and thus incompatible with the international norms and theoretical templates. The peculiarity of the Chinese experience, plus the lack of necessary information for meaningful studies, had made it extremely difficult for economic geography theorists and China geographers to have fruitful communication (see also Liu and Lu 2002). In recent years, however, the Chinese space-economy has undergone profound structural and spatial transformations as the post-Mao regime changed its approach from rigid utopian socialism to market-oriented pragmatism and from self-isolation to active participation in globalization. A fascinating mosaic of plan and market, state and private sectors, central authoritarianism, and local corporatism has emerged to recontour the economic landscape (G. C. S. Lin 1997;
Marton 2000; Wei 2000). Given the fundamental importance of both the Chinese culture and its restructured socialist institutional setting to the transformation of the Chinese space-economy, incorporating the Chinese case into the development of theory in mainstream economic geography seems to be timely and appropriate (e.g., Zhou and Tong in this issue).

Recent institutional and economic processes in China have not only invalidated our received wisdom of the geography of industrialization and economic transition, but also present themselves as fertile grounds for the development of new theories. First, economic geographers have been accustomed to industrialization occurring virtually hand in hand with rapid urbanization and industrial activities located within urban areas. The core geographic argument for this trend toward urban-biased industrialization is related to the Marshallian notion of agglomeration economies and, more recently, to increasing returns to scale, as demonstrated in the endogenous growth models (Martin and Sunley 1998). This abstract theorization of industrialization and regional growth, however, ignores historical specificity and institutional rigidities that continue to exert strong effects in the case of China. A process of rural industrialization has come to characterize the postreform pattern of industrialization in China through which the labor force is expected to stay in rural areas and industrial activities are brought to their doorsteps (Marton 2000). The enormous contributions of township and village enterprises (TVEs) to China's gross domestic products (GDP) and employment are one such indicator of the pervasive extent of rural industrialization. Widely scattered all over the vast countryside, the TVEs generated over 30 percent of China's GDP and provided employment opportunities to 27 percent of the total rural labor force by the year 2000 (Editorial Board 2001, 4-5). This finding, of course, does not mean that urban-centered industrialization does not take place in China. But it does call for a reconceptualization of industrialization and urban-regional development in China 
not as a special case of geographic industrialization, but as an original subject of inquiry that may yield new theoretical insights into urbanization, industrialization, rural development, and agrarian change.

Second, China's transitional economy allows for new theories of economic transition and organizational change that are just making significant inroads into the major social sciences, such as sociology and economics. Sociologists like Victor Nee (1989), Andrew Walder (1995), Nan Lin (1995; N. Lin and Bian 1991), and Doug Guthrie (1997) have worked on China's postreform development and collectively developed what may be termed the markettransition theory (see Stark 1996 and Pickles and Smith 1998 for the case of Eastern Europe). This theory has certainly reinvigorated sociological studies of changing social structures and economic organization in transitional economies. In economics, Barry Naughton (1991), Thomas Rawski (1994), Alwyn Young (2000), and others have shown how conventional neoclassical economics has failed to provide a valid theoretical model for explaining China's economic development (see also Amsden 1991; Young 1995). Alternative economic models are therefore called for that account for China's unprecedented economic transformations. Although we have not yet observed a similar theoretical development and disciplinary impact of research on Asia in economic geography, we have certainly noticed some novel conceptualizations arising from recent work on China (Hsing 1998; Olds 2001a; Fan 2002; Zhou and Tong in this issue) and other economies in East and Southeast Asia (Kelly 2001a, 2001b; Hsu and Saxenian 2000; Coe and Kelly 2002; Park in this issue).

To conclude this extended introduction to the special issue, we believe that theorizing economic geographies of Asia is clearly an unfinished intellectual project. In fact, we go so far as to suggest that it simply marks the beginning of a new intellectual era for economic geography toward the development of global economic geographies. Economic geographies of Asia must not be a subject of theorization from the perspec- tives of mainstream Anglo-American economic geography. But equally, they are too important to be left to Asian economic geographers alone. Building on a growing body of economic geography research on Asia, what we aim to achieve through this special issue is a further and, we hope, significant step toward more genuine theoretical dialogues among economic geographers with different regional interests. This bold aim cannot be achieved without more theoretical work that is grounded in the material realities of Asia but that speaks to an audience that is well tuned into the transmission frequency of global economic geographies. The future of economic geography must be bright and exciting. In this sense, we fully concur with Barnes and Sheppard's (2000, 6; our emphasis) assessment: "There is a Chinese saying: 'May you live in interesting times.' Our argument is that they are here now in economic geography." Obviously, we-both ethnic Chinese writers-cannot agree more.

\section{References}

Amin, A. 1997. Placing globalization. Theory, Culture and Society 14:123-37.

—. 1999. An institutionalist perspective on regional economic development. International Journal of Urban and Regional Research 23:365-78.

Amsden, A. 1989. Asia's next giant: South Korea and late industrialization. New York: Oxford University Press.

1. 1991. Diffusion of development: The late industrializing model and greater Asia. American Economic Review 81:282-6.

2001. The rise of "the rest": Challenges to the West from late-industrializing economies. New York: Oxford University Press.

Angel, D. P. 1994. Restructuring for innovation: The remaking of the U.S. semiconductor industry. New York: Guilford Press.

Aoyama, Y. 2000. Networks, keiretsu and locations of the Japanese electronics industry in Asia. Environment and Planning A 32:223-44.

Appadurai, A. 1999. Globalization and the research imagination. International Social Science Journal 51:229-38.

Armstrong, W., and McGee, T. G. 1985. Theatres of accumulation: Studies in Asian and Latin American urbanization. London: Methuen. 
Asheim, B. T. 2000. Industrial districts: The contributions of Marshall and beyond. In The Oxford handbook of economic geography, ed. G. L. Clark, M. A. Feldman, and M. S. Gertler, 413-31. Oxford, U.K.: Oxford University Press.

Barkema, H. 2001. From the editors. Academy of Management Journal 44:615-17.

Barnes, T. J. 1996. Logics of dislocation: Models, metaphors, and meanings of economic space. New York: Guilford Press.

_. 1999. Industrial geography, institutional economics and Innis. In The new industrial geography: Regions, regulation and institutions, ed. T. J. Barnes and M. S. Gertler, 1-22. London: Routledge.

-. 2000. Inventing Anglo-American economic geography, 1889-1960. In A companion to economic geography, ed. E. Sheppard and T. J. Barnes, 11-26. Oxford, U.K.: Blackwell.

- 2001a. Retheorizing economic geography: From the quantitative revolution to the "cultural turn." Annals of the Association of American Geographers 91:546-65.

- 2001b. Lives lived and lives told: Biographies of the quantitative revolution. Environment and Planning D: Society and Space 19:409-29.

—. 2001c. In the beginning was economic geography-a science studies approach to disciplinary history. Progress in Human Geography 25:521-44.

Barnes, T. J., and Curry, M. 1983. Towards a contextualist approach to geographical knowledge. Transactions of the Institute of British Geographers 8:467-82.

Barnes, T. J., and Sheppard, E. 2000. Introduction: The art of economic geography. In A companion to economic geography, ed. E. Sheppard and T. J. Barnes, 1-8. Oxford, U.K.: Blackwell.

Brenner, N. 1999. Globalization as reterritorialisation: The European re-scaling of urban governance in the European Union. Urban Studies 36:431-51.

Brohman, J. 1996. Postwar development in the Asian NICs: Does the neoliberal model fit reality? Economic Geography 72:107-30.

Bryson, J.; Henry, N.; Keeble, D.; and Martin, R., eds. 1999. The economic geography reader: Producing and consuming global capitalism. Chichester, U.K.: John Wiley \& Sons.

Bunnell, T. G., and Coe, N. M. 2001. Spaces and scales of innovation. Progress in Human Geography 25:569-90.
Cartier, C. 2001. Globalizing South China. Oxford, U.K.: Blackwell.

Clark, G. L. 1981. The employment relation and spatial division of labor: A hypothesis. Annals of the Association of American Geographers 71:412-24.

Clark, G. L.; Feldman, M. A.; and Gertler, M. S., eds. 2000. The Oxford handbook of economic geography. Oxford, U.K.: Oxford University Press.

Clark, G. L., and Kim, W. B., eds. 1995. Asian NIEs in the global economy. Baltimore, Md.: Johns Hopkins University Press.

Clegg, S. R., and Redding, S. G., eds. 1990. Capitalism in contrasting cultures. Berlin: de Gruyter.

Coe, N. M., and Kelly, P. F. 2002. Languages of labour: Representational strategies in Singapore's labour control regime. Political Geography 21:341-71.

Dicken, P. 2003. Global shift: Transforming the world economy. 4th ed. London: Sage.

Dicken, P.; Kelly, P.; Olds, K.; and Yeung, H. W.-c. 2001. Chains and networks, territories and scales: Towards an analytical framework for the global economy. Global Networks 1:89-112.

Dicken, P., and Thrift, N. 1992. The organization of production and the production of organization: Why business enterprises matter in the study of geographical industrialization. Transactions, Institute of British Geographers 17:279-91.

Douglass, M. 1994. The "developmental state" and the NIEs of Asia. Environment and Planning A 26:543-66.

Economic Geography 2002. Special issue on global economic change. 78(3).

Edgington, D. W., and Hayter, R. 2000. Foreign direct investment and the flying geese model: Japanese electronics firms in the Asia Pacific. Environment and Planning $A$ 32:281-304.

Editorial Board. 2001. Almanac of China's township and village enterprises (2001). Beijing: China Agricultural Press.

Eng, I. 1997. Flexible production in late industrialization: The case of Hong Kong. Economic Geography 73:26-43.

Fan, C. C. 2002. The elite, the natives, and the outsiders: Migration and labor market segmentation in urban China. Annals of the Association of American Geographers 91:103-24.

Fan, C. C.; Ma, L. J. C.; Pannell, C. C.; and Tan, K. C. Forthcoming. China geography in North America. In Geography in America at 
the dawn of the 21st century, ed. G. L. Gaile and C. J. Willmott. New York: Oxford University Press.

Florida, R., and Kenney, M. 1990. The breakthrough illusion. New York: Basic Books.

Frank, A. G. 1998. ReORIENT: Global economy in the Asian age. Berkeley: University of California Press.

Frobel, F.; Heinrichs, J.; and Kreye, O. 1980. The new international division of labour. Cambridge, U.K.: Cambridge University Press.

Geertz, C. 1973. The interpretation of cultures. New York: Basic Books.

Gertler, M. S. 2001. Best practice? Geography, learning and the institutional limits to strong convergence. Journal of Economic Geography 1:5-26.

Gertz, B. 2000. The China threat: How the People's Republic targets America. Washington, D.C.: Regnery.

Ginsburg, N. S., and Brush, J. E. 1958. The pattern of Asia. Englewood Cliffs, N.J.: Prentice Hall.

Goodhart, C., and Xu, C., 1996. The rise of China as an economic power. Cambridge, Mass.: Institute for International Development, Harvard University.

Granovetter, M. 1985. Economic action, and social structure: The problem of embeddedness. American Journal of Sociology 91:481-510.

Guthrie, D. 1997. Between markets and politics: Organizational responses to reform in China. American Journal of Sociology 102:1258-304.

Hamilton, G. G., and Biggart, N. W. 1988. Market, culture, and authority: A comparative analysis of management and organization in the Far East. American Journal of Sociology 94:S52-S94.

Hart-Landsberg, M., and Burkett, P. 1998. Contradictions of capitalist industrialization in East Asia: A critique of "flying geese" theories of development. Economic Geography 74:87-110.

Harvey, D. 1989. The condition of postmodernity: An enquiry into the origins of cultural change. Oxford, U.K.: Basil Blackwell.

Henderson, J. 1989. The globalisation of high technology production. London: Routledge.

Hsing, Y.-t. 1998. Making capitalism in China: The Taiwan connection. New York: Oxford University Press.

Hsu, J.-Y., and Cheng, L.-L. 2002. Revisiting economic development in post-war Taiwan: The dynamic process of geographical industrialization. Regional Studies 36:897-908.
Hsu, J.-Y., and Saxenian, A. 2000. The limits of Guanxi capitalism: Transnational collaboration between Taiwan and the USA. Environment and Planning A 32:1991-2005.

Hudson, B. 1977. The new geography and the new imperialism: 1870-1918. Antipode 9:12-19.

Johnson, C. 1982. MITI and the Japanese economic miracle, Stanford, Calif.: Stanford University Press.

Johnston, R. J. 1997. Geography and geographers: Anglo-American human geography since 1945, 5th ed. London: Arnold.

Kelly, P. F. 1999. The geographies and politics of globalization. Progress in Human Geography 23:379-400.

_ 2001a. The political economy of local labor control in the Philippines. Economic Geography 77:1-22.

—. 2001b. Metaphors of meltdown: Political representations of economic space in the Asian financial crisis. Environment and Planning D: Society and Space 19:719-42.

Kelly, P. F.; Olds, K.; and Yeung, H. W.-c. 2001. Introduction: Geographical perspectives on the Asian economic crisis. Geoforum 32:vii-xiii.

Kerr, D. 2002. The "place" of land in Japan's postwar development, and the dynamic of the 1980s real-estate "bubble" and 1990s banking crisis. Environment and Planning D: Society and Space 20:345-74.

Krugman, P. 1994. The myth of Asia miracle. Foreign Affairs 73:62-78.

_. 1998. Asia: What went wrong? Fortune $137(4): 32$.

Lee, R., and Wills, J., eds. 1997. Geographies of economies. London: Arnold.

Leeming, F. 1980. On Chinese geography. Progress in Human Geography 4:218-37.

Leung, C.-k. 1993. Personal contacts, subcontracting linkages, and development in the Hong Kong-Zhujiang Delta region. Annals of the Association of American Geographers 83:272-302.

Ley, D. 1999. Myths and meaning of immigration and the metropolis. Canadian Geographer 43:2-19.

Lin, G. C. S. 1997. Red capitalism in South China: Growth and development of the Pearl River Delta. Vancouver: University of British Columbia Press.

—. 2002a. Transnationalism and the geography of sub-ethnicity in Hong Kong. Urban Geography 23:57-84.

. 2002b. Changing discourses in China geography: A narrative evaluation. Environment and Planning A 34:1809-31. 
Lin, N. 1995. Local market socialism: Local corporatism in action in rural China. Theory and Society 24:301-54.

Lin, N., and Bian, Y. 1991. Getting ahead in urban China. American Journal of Sociology 97:657-88.

Liu, W., and Lu, D. 2002. Rethinking the development of economic geography in mainland China. Environment and Planning A 34:2107-126.

Ma, L. J. C., and Cartier, C., eds. 2003. The Chinese diaspora: Space, place, mobility and identity, Boulder, Colo.: Rowman \& Littlefield.

MacKinnon, D.; Cumbers, A.; and Chapman, K. 2002. Learning, innovation and regional development: A critical appraisal of recent debates. Progress in Human Geography 26:293-311.

Markusen, A., and Park, S. O. 1993. The state as industrial locator and district builder: The case of Changwon, South Korea. Economic Geography 69:157-81.

Martin, R., and Sunley, P. 1998. Slow convergence? The new endogenous growth theory and regional development. Economic Geography 74:201-27.

Marton, A. M. 2000. China's spatial economic development: Regional transformation in the lower Yangzi Delta. London: Routledge.

Massey, D. 1973. Towards a critique of industrial location theory. Antipode 5:33-9.

-1 1984. Spatial division of labour: Social structures and the geography of production. London: Macmillan.

McGee, T. G. 1967. The southeast Asian city. London: Bell.

- 1971. The urbanization process in the Third World: Explorations in search of $a$ theory. London: Bell.

The case of Asian urbanization. Canadian Geographer 35:332-44.

McGee, T. G., and Yeung, Y.-m. 1977. Hawkers in southeast Asian cities: Planning for the bazaar economy. Ottawa: International Development Research Centre.

Mitchell, K. 1995. Flexible circulation in the Pacific Rim: Capitalism in cultural context. Economic Geography 71:364-82.

Murphey, R. 1953. Shanghai: Key to modern China. Cambridge, Mass.: Harvard University Press.

Naughton, B. 1991. Why has economic reform led to inflation. American Economic Review 81:207-11.

Nee, V. 1989. A theory of market transition: From redistribution to markets in state socialism. American Sociological Review 54:663-81.
Ohmae, K. 1990. The borderless world: Power and strategy in the interlinked economy. London: Collins.

Olds, K. 2001a. Globalization and urban change: Capital, culture and Pacific Rim mega projects. New York: Oxford University Press.

—. 2001b. Practices for "process geographies": A view from within and outside the periphery. Environment and Planning D: Society and Space 19:127-36.

Olds, K., and Poon, J. 2002. Theories and discourses of economic geography. Environment and Planning A 34:379-83.

Olds, K., and Yeung, H. W.-c. 1999. (Re)shaping "Chinese" business networks in a globalising era. Environment and Planning D: Society and Space 17:535-55.

Pannell, C. W. 1980. Geography. In Science in contemporary China, ed. L. A. Orleans, 167-87. Stanford, Calif.: Stanford University Press.

Park, B.-G. 1998. Where do tigers sleep at night? The state's role in housing policy in South Korea and Singapore. Economic Geography 74:272-88.

Park, S. O., and Markusen, A. 1995. Generalizing new industrial districts: A theoretical agenda and an application from a non-Western economy. Environment and Planning A 27:81-104.

Patchell, J. 1993a. From production systems to learning systems-lessons from Japan. Environment and Planning A 25:797-815.

— 1993b. Composing robot production systems-Japan as a flexible manufacturing system. Environment and Planning A 25:923-44.

. 2002. Linking production and consumption. The coevolution of interaction systems in the Japanese house industry. Annals of the Association of American Geographers 92:284-301.

Peck, J. A., and Miyamachi, Y. 1994. Regulating Japan? Regulation theory versus the Japanese experience. Environment and Planning D: Society and Space 12:639-74.

Peck, J. A., and Yeung, H. W.-c., eds. 2003. Remaking the global economy: Economicgeographical perspectives. London: Sage.

Pickles, J., and Smith, A., eds. 1998. Theorising transition: The political economy of postCommunist transformations. London: Routledge.

Piore, M. J., and Sabel, C. F. 1984. The second industrial divide: Possibilities for prosperity. New York: Basic Books. 
Polanyi, K. 1944. The great transformation. New York: Holt, Rinehart.

Potter, R. 2001. Geography and development: "Core and periphery"? Area 33:422-7.

Radelet, S., and Sachs, J. D. 1998. The East Asian financial crisis: Diagnosis, remedies, prospects. Brookings Papers on Economic Activity 1:1-90.

Rawski, T. G. 1994. Chinese industrial reform: Accomplishments, prospects, and implications. American Economic Review 84:271-5.

Redding, S. G. 1990. The spirit of Chinese capitalism. Berlin: de Gruyter.

Reich, R. B. 1991. The work of nations: Preparing ourselves for 21 st century capitalism. New York: Vintage Books.

Said, E. W. 1978. Orientalism. London: Routledge.

Schoenberger, E. 1997. The cultural crisis of the firm. Oxford, U.K.: Basil Blackwell.

Scott, A. J. 1988. New industrial spaces: Flexible production, organisation and regional development in North America and Western Europe. London: Pion.

- 2000. Economic geography: The great half-century. Cambridge Journal of Economics 24:483-504.

Shaw, M. 2000. Theory of the global state: Globality as unfinished revolution. Cambridge, U.K.: Cambridge University Press.

Sheppard, E., and Barnes, T. J., eds. 2000. A companion to economic geography. Oxford, U.K.: Blackwell.

Sidaway, J. D. 1997. The production of British geography. Transactions of the Institute of British Geographers 22:488-504.

Skinner, G. W. 1964. Marketing and social structure in rural China (Part I). Journal of Asian Studies 24:3-44.

Slater, D. 1999. Situating geopolitical representations: Inside/outside and the power of imperial interventions. In Human Geography Today, ed. D. Massey, J. Allen, and P. Sarre, 62-84. Cambridge, U.K.: Polity Press.

Smith, A. 2002. Trans-locals, critical area studies and geography's others, or why "development" should not be geography's organising framework: A response to Potter. Area 34:210-3.

Spate, O. H. K. and Learmonth, A. T. A. 1967. India and Pakistan: A general and regional geography. London: Methuen.

Spencer, J. E. 1954. Asia, East by South: A cultural geography. New York: John Wiley \& Sons.

Stark, D. 1996. Recombinant property in East European capitalism. American Journal of Sociology 101:993-1027.
Stark, D., and Bruszt, L. 2001. One way or multiple paths: For a comparative sociology of East European capitalism. American Journal of Sociology 106:1129-37.

Stiglitz, J. E., and Yusuf, S., eds. 2001. Rethinking the East Asian miracle. Washington, D.C.: World Bank.

Storper, M., and Salais, R. 1997. Worlds of production: The action frameworks of the economy. Cambridge, Mass.: Harvard University Press.

Storper, M., and Walker, M. 1989. The capitalist imperative: Territory, technology and industrial growth. Oxford, U.K.: Basil Blackwell.

Taylor, P. J. 1996. Embedded statism and the social sciences: Opening up to new spaces. Environment and Planning A 28:1917-28.

Thrift, N., and Olds, K. 1996. Refiguring the economic in economic geography. Progress in Human Geography 20:311-37.

Thrift, N., and Walling, D. 2000. Geography in the United Kingdom 1996-2000. Geographical Journal 166:96-124.

Tyson, L. D'A. 1993. Who's bashing whom? Trade conflicts in high-technology industries. Washington, D.C.: Institute for International Economics.

Vogel, E. F. 1979. Japan as number one: Lessons for America. Cambridge, Mass.: Harvard University Press.

- 1989. One step ahead in China: Guangdong under reform. Cambridge, Mass.: Harvard University Press.

Wade, R. 1990. Governing the market: Economic theory and the role of government in East Asian industrialization. Princeton, N.J.: Princeton University Press.

- 2002. U.S. hegemony and the World Bank: The fight over people and ideas. Review of International Political Economy 9:215-43.

Wade, R., and Veneroso, F. 1998. The Asian crisis: The high debt model versus the Wall Street-Treasury-IMF complex. New Left Review 228:3-23.

Walder, A. G. 1995. Local governments as industrial firms: An organizational analysis of China's transitional economy. American Journal of Sociology 101:263-301.

Walker, R., and Storper, M. 1981. Capital and industrial location. Progress in Human Geography 5:473-509.

Wei, Y. D. 2000. Regional development in China: States, globalization, and inequality. London: Routledge.

Wheatley, P. 1971. The pivot of the four quarters: A preliminary enquiry into the origins 
and character of the ancient Chinese city. Chicago: Aldine.

Whitley, R. 1999. Divergent capitalisms: The social structuring and change of business systems. New York: Oxford University Press.

Wills, J., and Lee, R. 1997. Introduction. In Geographies of economies, ed. R. Lee and J. Wills, xv-xviii. London: Arnold.

Womack, J. P.; Jones, D. T.; and Roos, D. 1990. The machines that changed the world. New York: Rawson Associates.

World Bank 1993. The East Asian miracle. Oxford, U.K.: Oxford University Press.

Yeoh, B. S. A., and Chang, T. C. 2001. Globalising Singapore: Debating transnational flows in the city. Urban Studies 38:1025-44.

Yeung, H. W.-c. 1994. Critical reviews of geographical perspectives on business organisations and the organisation of production: Towards a network approach. Progress in Human Geography 18:460-90.

- 1997. Business networks and transnational corporations: A study of Hong Kong firms in the ASEAN region. Economic Geography 73:1-25.

. 1998a. The social-spatial constitution of business organisations: A geographical perspective. Organization 5:101-28.

2. 1998b. Capital, state and space: Contesting the borderless world. Transactions of the Institute of British Geographers 23:291-309.

- 1998c. Transnational corporations and business networks: Hong Kong firms in the ASEAN region. London: Routledge.

- 1999. Regulating investment abroad? The political economy of the regionalisation of Singaporean firms. Antipode 31:245-73.
2000. Organising "the firm" in industrial geography, I: Networks, institutions and regional development. Progress in Human Geography 24:301-15.

- 2001a. Redressing the geographical bias in social science knowledge. Environment and Planning A 33:2-9.

. 2001b. Regulating "the firm" and sociocultural practices in industrial geography, II. Progress in Human Geography 25:293-302.

_ 2002a. Doing what kind of economic geography? Journal of Economic Geography 2:250-2.

- 2002b. The limits to globalization theory: A geographical perspective on global economic change. Economic Geography 78:285-305.

—. Forthcoming. Practicing new economic geographies: A methodological examination. Annals of the Association of American Geographers 93(2).

Young, A. 1995. The tyranny of numbersConfronting the statistical realities of the East Asian growth experience. Quarterly Journal of Economics 110:641-80.

- 2000. The razor's edge: Distortions and incremental reform in the People's Republic of China. Quarterly Journal of Economics 115:1091-1135.

Zhou, Y. 1998. Beyond ethnic enclaves: Location strategies of Chinese producer service firms in Los Angeles. Economic Geography 74:228-51.

Zhou, Y., and Tseng, Y.-F. 2001. Regrounding the "Ungrounded Empires": Localization as the geographical catalyst for transnationalism. Global Networks 1:131-54. 